\title{
An Automated Agricultural Robot
}

\author{
Leenata Vedpathak ${ }^{1}$, Pooja Salape ${ }^{2}$, Snehal Naik ${ }^{3}$ \\ Student, ENTC, BVCOEW, Pune, India ${ }^{1,2,3}$
}

\begin{abstract}
The main aim of this proposed system is to measure of the N(nitrogen), $\mathrm{P}$ (phosphorus) and $\mathrm{K}$ (potassium) contents of soil and according to result, we can add the necessary elements in the soil. The N, P and K amounts in the soil sample is determined by comparing the solution with colour chart. This will describe amount of N, P and K ashigh, medium, low and none. The types of nutrients present in the soil - macronutrients (nutrients required in large quantities) and micronutrients (nutrients required in smaller quantities). Nitrogen, Phosphorus, Potassium are mainly required in large amount in soil. "NPK measurement, automatic seeding and fertilizer dispensing robot" system will check the amount of the three main fertilizers which are nitrogen, phosphorus and potassium in the soil and will dispense the required amount of nutrient. A NPK kit which is used for testing of the soil sample is in existence but the fertilizers dispensing is to be done manually. This problem will be rectified in this system. This proposed system will saves labour, time and obtain better results with using less amount of fertilizers. The same system can be used for seeding also.
\end{abstract}

Keywords: NPK measurement, digging, automatic seeding, fertilizer dispensing.

\section{INTRODUCTION}

Agriculture comes from two Latin words:

Ager which means a field.

culturia which means cultivation,

Due to traditional methods of agricultural process the Indian farmer faces many problems about productivity of agricultural product than other's. It is due to unbalance feeding of fertilizer without knowing the actual requirement of nutrient to a particular crop.

Now a day soil is tested in laboratory and proper analysis of soil is done and amount of various contains and their ratio are measured but laboratories are normally in district places and it is little bit time consuming process. This proposed system contributes to give contain of NPK in soil within some minutes.

N(Nitrogen)- for growth of leaves and vegetation. $\mathrm{P}$ (Phosphorus)-for root and growth.

$\mathrm{K}$ (Potassium)-regulation of water and nutrient in plant cell, flowering, fruiting.

Seeding is one of the main process of farming activity. It also takes more man power that can be reduced with this system, seeding is automated which helps linear way of seeding and time consumption is reduced.

The NPK value is measured and compared with the standard value for particular crop is known so the difference amount of fertilizer is dispensed by robot.

\section{PROPOSED SYSTEM DESCRIPTION}

The working of proposed system is divided in to three parts first is NPK measurement, second is automatic seeding and last is fertilizer dispensing in farm for this schematic block diagram is shown in fig. 1 the system consist of colour sensor, ARM 7 controller, LCD, Solenoid valve like arrangement etc.

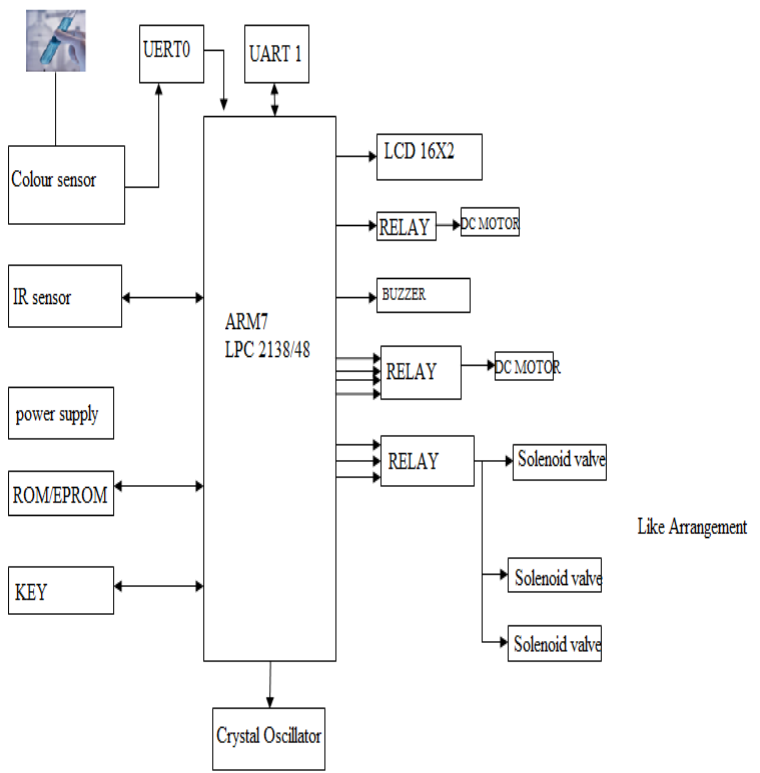

A. Colour Sensor

It will detect the colour based on the combination of three basic colour components RGB.

\section{B. ARM -7 Controller}

ARM7 used is LPC2138/48 operates at $11.05 \mathrm{MHz}$. It plays an important role, it processes the data received by colour sensor and compare data with the data which is already stored in controller according to the sensor output signal.

\section{$C . \quad L C D$}

The LCD receives control signal from the microcontroller; it decodes that control signal and performs the corresponding actions on LCD. Once the initialization sequence is done, it displays the soil parameters. It is used to display the amount of fertilizers in the soil.

D. $\quad$ Solenoid Valve Like Arrangement

In this system solenoid valve like arrangement is used to drop the seeds in farm when seeding is to be done by robot. 


\section{WORKING OF THE SYSTEM}

The soil sample is taken from the farm, the proper amount of water is added and sample and solution is made. The sample water is tasted with some chemicals which are present in NPK measurement kit. The colour sensor will sense the solution colour and give input to the controller, the controller will take appropriate valve according to the pre-stored colour chart in it, then that value will be displayed on LCD.

The next step is seeding, the high power motor is used for providing high torque on sharp pointed edge like arrangement which is used for digging purpose and IR sensor takes the responsibility of 5-6 seeds that should be dispensed at a time.

The important work is of dispensing proper amount of fertilizers in field. For this the resultant value of comparison is taken in to consideration and with the help of solenoid valve like arrangement fertilizers are dispensed in the soil. The opening and closing of the valve is controlled by motor which is connected to shaft of valve. The dispensing of fertilizer is done on the unit base system.

\section{RESULT}

The main focus of this system is on measurement of different macronutrients like $\mathrm{N}, \mathrm{P}$ and $\mathrm{K}$, besides these some other nutrients are also present in the soil like-Calcium(Ca), Magnesium(Mg), Sulphur(S), Manganese(Mn), Molybdenum(Mo), Boron(B), Copper $(\mathrm{Cu})$ etc. can be measured with the help of some laboratory processes.

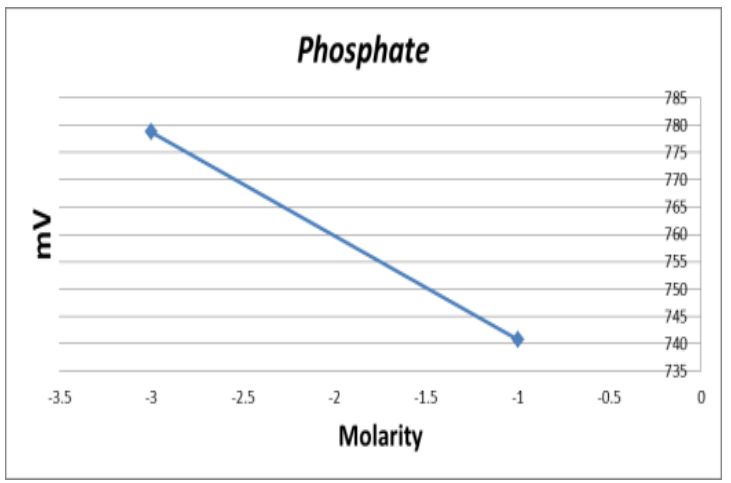

Fig.1 proposed result of phosphate [1]

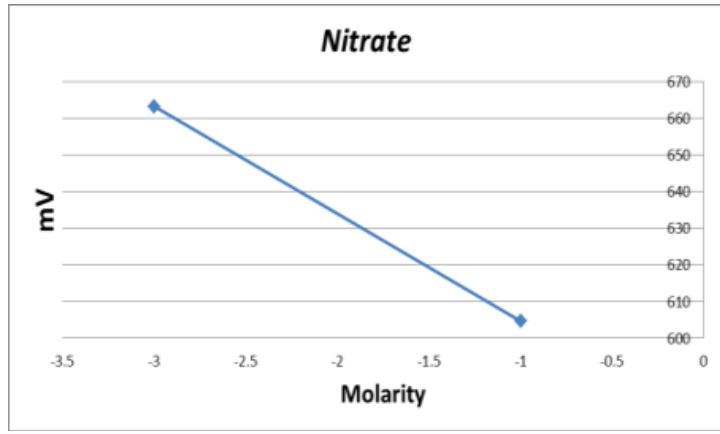

Fig. 2 proposed result of nitrogen [1]

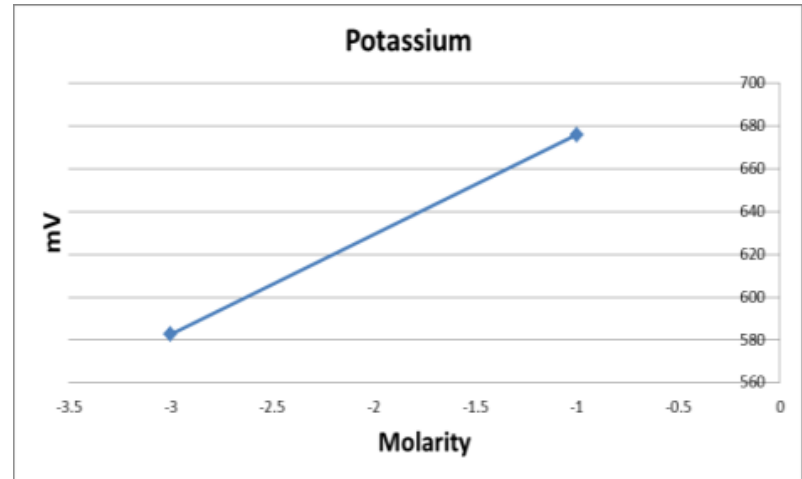

Fig 3. Proposed result of potassium [1]

V.

CONCLUSION

This system has been developed for NPK measurement of soil. The values of $\mathrm{N}, \mathrm{P}, \mathrm{K}$ are varies from one type of soil to other. It gives the information about which crop can be taken from respective soil.

\section{ACKNOWLEDGEMENT}

We would like to thank principle Prof. Dr D. S. BILGI and also extend our thanks to our head of department Prof.Dr.S.R.PATIL for inspiring us.We would like to take this opportunity to express true sense of gratitude towards our project guide Prof.S.L.KORE for her valuable co-operation and gratitude that she gave us throughout the project.

\section{REFERENCES}

[1] Green Growth Management by Using Arm Controller, B Yogesh Ramdas et al Int. Journal of Engineering Research and Applications ISSN : 2248-9622, Vol. 4, Issue 3( Version 1), March 2014, pp.360-363

[2] D.S.Suresh, Jyothi Prakash K V, Rajendra C J, "Automated Soil Testing Device", ITSI Transactions on Electrical and Electronics Engineering (ITSI-TEEE) ISSN (PRINT) : 2320 - 8945, Volume 1 , Issue $-5,2013$

[3] Soil Testing in India", Department of Agriculture \& Co-operation, Ministry of Agriculture, Government of India, New Delhi, January, 2011.

[4] Sneha J. Bansod, Shubhadha Thakre, "Near Infrared Spectroscopy based Soil Nitrogen measurement", International Journal of Current Engineering and Technology E-ISSN 2277 - 4106, P-ISSN 2347 - 5161.

\section{BIOGRAPHY}

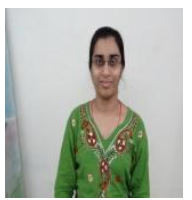

Leenata Vedpathak, a student of B.E. E\&TC from Bharati Vidyapeeth's College of Engineering for Women, Katraj, Pune411043. We won "Best Idea Award" for project concept from PVG COET, Pune.

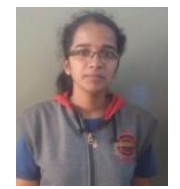

Pooja Salape, a student of B.E. E\&TC from Bharati Vidyapeeth's College of Engineering For Women, Pune 411043.

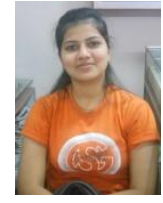

Snehal Vinayak Naik, a student of B.E. E\&TC from Bharati Vidyapeeth's College of Engineering for Women, Katraj, Pune411043. Won the "Best Idea" Award in project competition held in PVG's COET . 